\title{
FILSAFAT KURIKULUM DAN PENGAJARAN
}

\author{
Yusuf Seknun \\ Fakultas Tarbiyah dan Keguruan \\ Universitas Islam Negeri Alauddin Makassar \\ Jl. H. M. Yasin Limpo No. 36 Samata, Gowa
}

\begin{abstract}
First of all, on the background of philosophy required an ontological basis of the science of education. The aspect of reality that reaches the theory and science of education through the experience of the senses is the world of human experience empirically. Object material science education is a complete human, complete human aspects of his personality, namely humans who have noble character in the educational situation or expected beyond human beings as social beings remember as a citizen he has the characteristics of good citizens (good citizenship or the best citizenship). The epistemological basis is required by education or science education experts to develop their knowledge productively and responsibly. Although data collection in the field can be partially performed by novice personnel but the study of the formal object of the science of education reveals a phenomenological approach that will establish an empirical study with a qualitative-phenomenological study. The phenomenological approach is qualitative, meaning it involves the personal and self-researcher as a data collection instrument in post-positivism. Therefore, the study and data collection is directed by educators or scientists as experts who are honest and united with the object.
\end{abstract}

Keywords: Curriculum, Philosophy, Education and Teaching

\section{PENDAHULUAN}

$\Gamma$ Terdapat cukup alasan yang baik untuk belajar filsafat,khususnya apabila ada pertanyaan-pertanyaan rasional yang tidak dapat atau sayogyanya tidak dijawab oleh ilmu atau cabang ilmu-ilmu,misalnya :apakah yang dimaksud dengan pengetahuan dan /atau ilmu?Dapatkah kita bregerak ke kiri dan kanan didalam ruang tetapi tidak terikat oleh waktu?masalah yang dibahas dalam makalah ini adalah sekitar pendidikan dan ilmu pendidikan.Kiranya kegiatan pendidikan bukanlah sekedar gejala social yang bersifat rasional semata mengingat kita mengharapkan pendidikan yang terbaik untuk bangsa Indonesia.lebih-lebih untuk anak-anak kita masing-masing: ilmu pendidikan secara umum sosial dan biologi tetapi tidak berarti bahwa ilmu pendidikan itu sekedar ilmu atau suatu studi terapan berdasarkan hasil-hasil yang dicapai oleh ilmuilmu social dan atau ilmu prilaku

Menurut Redja M ( Depdikbud : IKIP Bandung, 199 1),Praktek pendidikan adalah seperangkat kegiatan bersama yang bertujuan membantu pihak lain agar mengalami perubahan tingkah laku yang diharapkan.Praktik pendidiakna dapat dilihat dari tiga aspek,yakni aspek,tujuan,aspek proses kegiatan,aspek dorongan (motivasi).Dalam 
kaitan ini Prof.Sikun Pribadi (1980) mengemukakan: itulah sebabnya mengapa suatu uapaya pendidikan tidak dapat dan tidak boleh dikemukakan dalam bentuk resep atau aturan yang tetap untuk dijalankan yang penting bukan resepnya,melainkan kepribadian dan kreativitas pendidikan sendiri. Pendidikan (walaupun harus didukung oleh ilmu pendidikan atau pedagogik) dalam pelaksanaanya lebih merupakan seni dari pada teori”.

\section{PEMBAHASAN}

\section{A. Pendidikan Sebagai Kegiatan Ilmu dan Seni}

Masalah pendidikan mikro yang menjadi focus disini khususnya ialah dasar dan landasan pendidikan serta landasan ilmu pendidikan yaitu manusia atau sekelompok kecil manusia dalam fenomena pendidikan.

1. Pendidikan dalam Praktek Memerlukan teori

Alangkah pentingnya kita berteori dalam praktek di lapangan pendidikan karena pendidikan dalam praktek harus dipertanggungjawabkan. Tanpa teori dalam arti seperangkat alasan dan rasional yang konsisten dan saling berhubungan maka tindakantindakan dalam pendidikan hanya didasarkan atas alasan-alasan yang kebetulan, seketika dan aji mumpung. Hal itu tidak boleh teijadi karena setiap tindakan pendidikan bertujuan menunaikan nilai yang terbaik bagi peserta didik dan pendidik. Bahkan pengajaran yang baik sebagai bagian dari pendidikan selain memerlukan proses dan alasan rasional serta intelektual juga teijalin oleh alasan yang bersifat moral. Sebabnya ialah karena unsur manusia yang aididik dan memerlukan pendidikan adalah makhluk manusia yang harus menghayati nilai-nilai agar mampu mendalami nilai-nilai dan menata perilaku serta pribadi sesuai dengan harkat nilai-nilai yang dihayati itu.

Kita baru saja menyaksikan pendidikan di Indonesia gagal dalam praktek berskala makro dan mikro yaitu dalam upaya bersama mendalami, mengamalkan dan menghayati Pancasila. Lihatlah bagaimana usaha nasional besar-besaran selama 20 tahun (1978-1998) dalam P-7 (Pembinaan Pendidikan Pelaksanaan Pedoman Penghayatan dan Pengamalan Pancasila) berakhir kita nilai gagal menyatukan bangsa untuk memecahkan masalah nasional suksesi kepresidenan secara damai tahun 1998, setelah krisis multidimensional melanda dan memporakporandakan hukum dan perekonomian negara mulai pertengahan tahun 1997, bahkan sejak 27 Juli 1996 sebelum kampanye Pemilu berdarah tahun 1997. itu adalah contoh pendidikan dalam skala makro yang dalam teorinya tidak pas dengan Pancasila dalam praktek diluar ruang penataran. Mungkin penatar dan petatar dalam teorinya ber-Pancasila tetapi didalam praktek, sebagian besar telah cenderung menerapkan Pancasila Plus atau Pancasila Minus atau kedua-duanya. Itu sebabnya harus kita putuskan bahwa P-7 dan P-4 tidak dapat dipertanggungjawabkan, setidak-tidaknya secara moral dan sosial. Mari kita kembali berprihatin sesuai ucapan Dr. Gunning yang dikutip Langeveld (1955).

"Praktek tanpa teori adalah untuk orang idiot dan gila, sedangkan teori praktek hanya untuk orang-orang jenius". Ini berarti bahwa sebaiknya pendidikan tidak 
dilakukan kecuali oleh orang-orang yang mampu bertanggung jawab secara rasional, sosial dan moral. Sebaliknya apabila pendidikan dalam praktek dipaksakan tanpa teori dan alasan yang memadai maka hasilnya adalah bahwa semua pendidik dan peserta didik akan merugi. Kita merugi karena tidak mampu bertanggung jawab atas esensi perbutan masing-masing dan bersama-sama dalam pengamalan Pancasila Pancasila yang baik dan memadai, konsisten antara pengamalan (lahiriah) dan penghayatan (psikologis) dan penataan nilai secara internal. Dalam hal ini kita bukan menyaksikan kegiatan (praktek) pendidikan tanpa dasar teorinya tetapi suatu praktek pendidikan nasional tanpa suatu teori yang baik.

\section{Landasan Sosial dan Individual Pendidikan}

Pendidikan sebagai gejala sosial dalm kehidupan mempunyai landasan individual, sosial dan cultural. Pada skala mikro pendidikan bagi individu dan kelompok kecil beralngsung dalam skala relatif tebatas seperti antara sesama sahabat, antara seorang guru dengan satu atau sekelompok kecil siswanya, serta dalam keluarga antara suami dan isteri, antara orang tua dan anak serta anak lainnya. Pendidikan dalam skala mikro diperlukan agar manusia sebagai individu berkembang semua potensinya dalam arti perangkat pembawaanya yang baik dengan lengkap. Pada skala makro pendidikan berlangsung dalam ruang lingkup yang besar seperti dalam masyarakat antar desa, antar sekolah, antar kecamatan, antar kota, masyarakat antar suku dan masyarakat antar bangsa.

Dalam skala makro masyarakat melaksanakan pendidikan bagi regenerasi sosial yaitu pelimpahan harta budaya dan pelestarian nilai-nilai luhur dari suatu generasi kepada generasi muda dalam kehidupan masyarakat Diharapkan dengan adanya pendidikan dalam arti luas dan skala makro maka perubahan sosial dan kestabilan masyarakat berangsung dengan baik dan bersama-sama. Pada skala makro ini pendidikan sebagai gejala sosial sering terwujud dalam bentuk komunikasi terutama komunikasi dua arah. Dilihat dari sisi makro, pendidikan meliputi kesamaan arah dalam pikiran dan perasaan yang berakhir dengan tercapainya kemandirian oleh peserta didik. Maka pendidikan dalam skala makro cenderung dinilai bersifat konservatif dan tradisional karena sering terbatas pada penyampaian bahan ajar kepada peserta didik dan bisa kehilangan ciri interaksi yang afektif.

3. Teori Pendidikan Memadu Jalinan Antara llmu dan Seni

Adanya aspek-aspek lahiriah, psikologis dan rohaniah seperti disebut tadi mengisyaratkan bahwa manusia dalam fenomena (situasi) pendidikan adalah paduan antara manusia sebagai sebagai fakta dan manusia sebaai nilai. Tiap manusia bemilai tertentu yuang bersifat luhur sehingga situasi pendidikan memiliki bobot nilai individual, sosial dan bobot moral. Itu sebabnya pendidikn dalam praktek adalah fakta empiris yang syarat nilai berhubung interaksi manusia dalam pendidikan tidak hanya timbal balik dalam arti komunikasi dua arah melainkan hams lebih tinggi mencapai tingkat maniusiawi seperti saya atau siswa mendidik diri sendiri atas dasar hubungan 
pribadi dengan pribadi (higher order interactions) antar individu dan hubungan intrapersonal secara afektif antara saya (yaitu I) dan diriku (diri sendiri yaitu my self atau the self).

Adapun manusia sebagai fakta empriris tentu meliputi berbagai variabel dan hubungan variabel yang terbatas jumlahnya dalam telaah deskriptif ilmu- ilmu. Sedangkan jumlah variabelnya amat banyak dan hubungan-hubungan antara variabel amat kompleks sifatnya apabila pendidik memelihara kualitas interaksinya dengan peserta didik secra orang perorang (personal).

Sepeti dikatakan tentang siswa belajar aktif oleh Phenix (1958:40), yaitu: "It possible to conceive of teacher and student as one and same person and the self taught person as one who direct his own development through an internal interaction between the self as I and the self as me on the other hand, it is usual for one teacher to teach many students simultaneously. In that even the quality oef the interaction may become generalized and impersonal, or it may, by appropriate means, retain its person to person character".

Artinya sift manusiawi dari pendidikan (manusia dalam pendidikan) hams terpelihara demi kualitas proses dan hasil pendidikan. Pemeliharaan itulah yang menuntut agar pendidik siap untuk bertindak sewaktu-waktu secara kreatif (berkiat menciptakan situasi yang pas, apabila perlu. Misalnya atas dasar diagnostik klinis) sekalipun tanpa prognosis yang lengkap namun utamanya berdasarkan sikap afektif bersahabat terhadap terdidik. Kreativitas itu didasarkan kecintaan pendidik terhadap tugas mendidik dan mengajar, itu sebabnya gejala atau fenomena pendidikan tidak dapat direduksi sebagai gejala sosial atau gejala komunikasi timbal balik belaka. Apabila ilmu-ilmu sosial atau behavioral mampu menerapkan pendekatan dan metode ilmiah (Pearson, 1900) secara termodifikasi dalam telaah manusia melalui gejala-gejala sosial, apakah ilmu pendidikan hams bertindak sempa untuk mengatasi ketertinggalan- nya khususnya ditanah air kita? Atau seperti dikatakan secara ilmiah oleh NL. Gage (1978:20).

Maka konsep pendidikan yang memerlukan ilmu fdan seni ialah proses atau upaya sadar antar manusia dengan sesama secara beradab, dimana pihak kesatu secara terarah membimbing perkembangan kemampuan dan kepribadian pihak kedua secara manusiawi yaitu orang perorang. Atau bisa diperluas menjadi makro sebagai upaya sadar manusia dimana warga maysrakat yang lebih dewasa dan berbudaya membantu pihak-pihak yangkurang mampu dan kurang dewasa agar bersama-sama mencapai taraf kemampuan dan kedewasaan yang lebih baik (Phenix, 1958:13), Buller, 1968:10). Dalam arti ini juga sekolah laboratorium akan memerlukan jalinan praktek ilmu dan praktek seni. Sebaliknya butir 1 pasal 1, UU No. 2 /1989 kiranya kurang tepat sehingga tentu sulit menuntut siswa ber CBSA padahal guru belum tentu aktif belajar, mengingat defmisi pendidikan yang makro, yaitu: "Pendidikan ialah usaha sadar untuk mempersiapkan peserta didik melalui kegiatan bimbingan, pengajaran dan atau latihan 
bagi peranannya dimasa yang akan dating".

Kiranya konsep pendidikan yang demikian yang demikian kurang mampu memberi isi kepada tujuan dan semangat Bab XIII UUD 1945 yang merujuk bidang pendidikan sebagai amanah untuk mewujudkan keterkaitan erat antara sistem pengajaran nasional dengan kebudayaan kebangsaan. Karena itu dalam lingkup pendidikan menurut skala mikro dan abstark yang lebih makro, pendidik harus juga peduli dengan aspek etis (moral) dan estetis dari pengalamannya berinteraksi dengan peserta didik selain aspek pengetahuan, kebenaran dan perilaku yang disisyaratkan oleh konsep pendidikan menurut undang-undang tadi. Hal ini sesuai dengan pandangan Ki Hajar Dewantara (1950) sebagai berikut:

"Taman Siswa mengembangkan suatu cara pendidikan yang tersebut didalam Among dan bersemboyan 'Tut Wuri Handayani' (mengikuti sambil mempengaruhi). Arti Tut Wuri aialah mengikuti, namun maknanya ialah mengikuti perkembangan sang anak dengan penuh perhatian berdasarkan cinta kasih dan tanpa pamrih, tanpa keinginan menguasai dan memaksa, dan makna Handayani ialah mempengaruhi dalam arti merangsang, memupuk, membimbing, memberi teladan gar sang anak mengembngkan pribadi masing- masing melalui disiplin pribadi”.

Demikian bagi Ki Hajar Dewantara pendidikan pada skala mikro tidak terlepas dari pendidikan dalam arti makro, bahkan disipilin pribadi adalah tujuan dan cara dalam mencapai disiplin yang lebih luas. Ini berarti bahwa landasan pendidikan terdapat dalam pendidikan itu sendiri, yaitu factor manusianya. Dengan demikian landasan-landasan pendidikan tidak mesti dicari diluar fenomena (gejala) pendidikan termasuk ilmu-ilmu lain dan atau filsafat tertentu dari budaya barat. Oleh karena itu data ilmu pendidikan tidak tergantung dari studi ilmu psikologi, fisiologi, sosiologi, antropologi ataupun filsafat. Lagi pula konsep pengajaran (yang makro) berdasarkan kurikulum formal tidak dengan sendirinya bersifat inklusif dan atau sama dengan mengajar. Bahkan dalam banyak hal pengajaran itu tergantung hasilnya dari kualitas guru mengajar dalam kelas masing-masing. Sudah barang tentu asas Tut Wuri Handayani tidak akan menjadikan pengajaran identik dengan sekedar upaya sadar menyampaikan bahan ajar dikelas kepada rombongan siswa mengingat guru harus berhamba kepada kepentingan siswanya.

\section{B. Dasar-dasar Filsafat Ilmu Pendidikan}

Baiklah sekarang kita lihat dasar-dasaar fdsafah keilmuan terkait dalam arti dasar ontologis, dasar epistemologis, dan aksiologis, dan dasar antropolgis ilmu pendidikan.

\section{Dasar Ontologis Ilmu Pendidikan}

Pertama-tama pada latar filsafat diperlukan dasar ontologis dari ilmu pendidikan. Adapun aspek realitas yang dijangkau teori dan ilmu pendidikan melalui pengalaman pancaindra ialah dunia pengalaman manusia secara empiris. Objek materil ilmu pendidikan ialah manusia seutuhnya, manusia yang lengkap aspek- aspek kepribadiannya, yaitu manusia yang berakhlak mulia dalam situasi pendidikan atau 
diharapokan melampaui manusia sebagai makhluk sosial mengingat sebagai warga masyarakat ia mempunyai ciri warga yang baik (good citizenship atau kewarganegaraan yang sebaik-baiknya)

Agar pendidikan dalam praktek terbebas dari keragu-raguan, maka objek formal ilmu pendidikan dibatasi pada manusia seutuhnya di dalam fenomena atau situasi pendidikan. Didalam situiasi sosial manusia itu sering berperilaku tidak utuh hanya menjadi makhluk berperilaku individual dan/atau makhluk sosial yang berperilaku kolektif. Hal itu boleh-boleh saja dan dapat diterima terbatas pada ruang lingkup pendidikan makro yang berskala besar mengingat adanya konteks sosio-budaya yang terstruktur oleh sistem nilai tertentu. Akan tetapipada latar mikro, sistem nilai harus terwujud dalam hubungan inter dan antar pribadi yang menjadi syarat mutlak (conditio sine qua non) bagi terlaksananya mendidik dan mengajar, yaitu kegiatan pendidikan yang berskala mikro. Hal itu teijadi mengingat pihak pendidik yang berkepribadiaan sendiri secara utuh memperlakukan peserta didiknya secara terhormat sebagai pribai pula, terlpas dari factor umum, jenis kelamin ataupun pembawaanya. Jika pendidik tidak bersikap afektif utuh demikian makaa menurut Gordon (1975: Ch. I) akan teijadi mata rantai yang hilang (the missing link) atas factor hubungan serta didik-pendidik atau antara siswa-guru. Dengan egitu pendidikan hanya akan teijadi secar kuantitatif sekalipun bersifat optimal, misalnya hasil THB summatif, NEM atau pemerataan pendidikan yang kurang mengajarkan demokrasi jadi kurang berdemokrasi. Sedangkan kualitas manusianya belum tentu utuh.

2. Dasar Epistemologis Ilmu Pendidikan

Dasar epistemologis diperlukan oleh pendidikan atau pakar ilmu pendidikan demi mengembangkan ilmunya secara produktif dan bertanggung jawab. Sekalaipun pengumpulan data di lapangan sebagaian dapat dilakukan oleh tenaga pemula namuntelaah atas objek formil ilmu pendidikan memerlukaan pendekatan fenomenologis yang akan menjalin stui empirik dengan studi kualitatif-fenomenologis. Pendekaatan fenomenologis itu bersifat kualitaatif, artinya melibatkan pribadi dan diri peneliti sabagai instrumen pengumpul data secara pasca positivisme. Karena itu penelaaah dan pengumpulan data diarahkan oleh pendidik atau ilmuwan sebagaai pakar yang jujur dan menyatu dengan objeknya. Karena penelitian tertuju tidak hnya pemahaman dan pengertian (verstehen, Bodgan \& Biklen, 1982) melainkan unuk mencapai kearifan (kebijaksanaan atau wisdom) tentang fenomen pendidikan maka vaaliditas internal harus dijaga betul dalm berbagai bentuk penlitian dan penyelidikan seperti penelitian koasi eksperimental, penelitian tindakan, penelitian etnografis dan penelitian ex post facto. Inti dasar epistemologis ini adalah agar dapat ditentukan bahaawa dalam menjelaskaan objek formaalnya, telaah ilmu pendidikan tidaak hanya mengembangkan ilmu terapan melainkan menuju kepada telaah teori dan ilmu pendidikan sebgaai ilmu otonom yang mempunyi objek formil sendiri atau problematika sendiri sekalipun tidak dapat hnya menggunkaan pendekatan kuantitatif atau pun 
eksperimental (Campbell \& Stanley, 1963). Dengan demikian uji kebenaran pengetahuan sangat diperlukan secara korespondensi, secara koheren dan sekaligus secara praktis dan atau pragmatis (Randall \&Buchler,1942).

3. Dasar aksiologis ilmu pendidikan

Kemanfaatan teori pendidikan tidak hanya perlu sebagai ilmu yang otonom tetapi juga diperlukan untuk memberikan dasar yang sebaik-baiknya bagi pendidikan sebagai proses pembudayaan manusia secara beradab. Oleh karena itu nilai ilmu pendidikan tidak hanya bersifat intrinsic sebagai ilmu seperti seni untuk seni, melainkan juga nilai ekstrinsik dan ilmu untuk menelaah dasar-dasar kemungkinan bertindak dalam praktek mmelalui kontrol terhadap pengaruh yang negatif dan meningkatkan pengaruh yang positif dalam pendidikan. Dengan demikian ilmu pendidikan tidak bebas nilai mengingat hanya terdapat batas yang sangat tipis antar pekeijaan ilmu pendidikan dan tugas pendidik sebagi pedagok. Dalam hal ini relevan sekali untuk memperhatikan pendidikan sebagai bidang yang sarat nilai seperti dijelaskan oleh Phenix (1966). Itu sebabnya pendidikan memerlukan teknologi pula tetapi pendidikan bukanlah bagian dari iptek. Namun harus diakui bahwa ilmu pendidikan belum jauh pertumbuhannya dibandingkan dengan kebanyakan ilmu sosial dan ilmu prilaku. Lebih-lebih di Indonesia.

Implikasinya ialah bahwa ilmupendidikan lebih dekat kepada ilmu prilaku kepada ilmu-ilmu sosial, dan harus menolak pendirian lain bahwa di dalam kesatuan ilmu-ilmu terdapat unifikasi satu-sayunyaa metode ilmiah (Kalr Perason,1990).

4. Dasar antropologis ilmu pendidikan

Pendidikan yang intinya mendidik dan mengajar ialah pertemuan antara pendidik sebagai subjek dan peserta didik sebagai subjek pula dimana teijadi pemberian bantuan kepada pihak yang belakangan dalaam upaayanya belajr mencapai kemandirian dalam batas-batas yang diberikan oleh dunia disekitamya. Atas dasar pandangan filsafah yang bersifat dialogis ini maka 3 dasar antropologis berlaku universal tidak hanya (1) sosialitas dan (2) individualitas, melainkan juga (3) moralitas. Kiranya khusus untuk Indonesia apabila dunia pendidikan nasional didasarkan atas kebudayaan nasional yang menjadi konteks dari sistem pengajaran nasional disekolah, tentu akan diperlukan juga dasar antropologis pelengkap yaitu (4) religiusitas, yaaitu pendidik dalam situasi pendidikan sekurangkurangnya secara mikro berhamba kepada kepentingan terdidik sebagai bagian dari pengabdian lebih bssar kepada Tuhan Yang Maha Esa.

\section{Perangkat Asumsi Filosofis Pendidikan Guru}

Program Pendidikan Guru Berdasarkan Kompetensi (PGBK) dikembangakan bertolak dari perangkat kompetensi yang diperkirakan dipersyaratkan bagi pelaksanaan tugas-tugas keguruan dan kependidikan yang telah ditetapkan dan bermuara pada pendemonstrasian perangkat kompetensi tersebut oleh siswa calon guru setelah mengikuti sejumlah pengalaman belajar. 
Perangkat kompetensi yang dimaksud, termasuk proses pencapaiannya, dilandasi oleh asumsi-asumsi filosofis, yaitu pertanyaan-pertanyaan yang dianggap benar, baik atas dasar bukti-bukti empirik, dugaan-dugaan maupun nilai-nilai masyarakat berdasarkan Pancasila. Asumsi-asumsi tersebut merupakan batu ujian di dalam menilai perancangan dan implementasi program dari penyimpangan-penyimpangan pragmatis ataupun dari serangan-serangan konseptual.

Asumsi-asumsi yang dimaksud mencakup 7 bidang yaitu yang berkenaan dengan hakekat-hakekat manusia, masyarakat, pendidikan, subjek didik, guru, belajar-mengajar dan kelembagaan. Tentu saja hasil keija tersebut diatas perlu dimantapkan dan diverifikasi lebih jauh melalui forum-forum yang sesuai seperti

Komisi Kurikulum, Konsorsium Ilmu Kependidikan, LPTK bahkan kalangan yang lebih luas lagi. Hasil rumusan tim pembaharuan pendidikan (1984) dapat disimpulkan sebagai berikut:

\section{Hakekat Manusia}

a. Manusia sebagai makhluk Tuhan mempunyai kebutuhan bertaqwa kepada Tuhan Yang Maha Esa.

b. Manusia membutuhkan lingkungan hidup berkelompok untuk mengembangkan dirinya.

c. Manusia mempunyai potensi-potensi yang dapat dikembangkan dan kebutuhan-kebutuhan materi serta spiritual yangharus dipenuhi.

d. Manusia itu pada dasamya dapat dan harus dididik serta dapat mendidik diri sendiri.

\section{Hakekat Masvarakat}

a. Kehidupan masyarakat berlandaskan sistem nilai-nilai keagamaan, sosial dan budaya yang dianut warga masyarakat; sebagian daripada nilai-nilai tersebut bersifat lestari dan sebagian lagi terns berubah sesuai dengan perkembangan ilmu dan teknologi.

b. Masyarakat merupakan sumber nilai-nilai yang memberikan arah normative kepada pendidikan.

c. Kehidupan bermasyarakat ditingkatkan kualitasnya oleh insane-insan yang berhasil mengembangkan dirinya melalui pendidikan.

\section{Hakekat Pendidikan}

a. Pendidikan merupakan proses interaksi manusiawi yang ditandai keseimbangan antara kedaulatan subjek didik dengan kewibawaan pendidik.

b. Pendidikan merupakan usaha penyiapan subjek didik menghadapi lingkungan yang mengalami perubahan yang semakin pesat.

c. Pendidikan meningkatkan kualitas kehidupoan pribadi dan masyarakat.

d. Pendidikan berlangsung seumur hidup.

e. Pendidikan merupakan kiat dalam menerapkan prinsip-prinsip ilmu 
pengetahuan dan teknologi bagi pembentukan manusia seutuhnya.

\section{Hakekat Subjek Didik}

a. Subjek didik betanggungjawab atas pendidikannya sendiri sesuai dengan wawasan pendidikan seumur hidup.

b. Subjek didik memiliki potensi, baik fisik maupun psikologis yang berbedabeda sehingga masing-masing subjek didik merupakan insane yang unik.

c. Subjek didik merupakan pembinaan individual serta perlakuan yang manusiawi.

d. Subjek didik pada dasamya merupakan insane yang aktif menghadapi lingkungan hidupnya.

\section{Hakekat Guru dan Tenadga Kependidikan}

a. Guru dan tenaga kependidikan merupakan agen pembaharuan.

b. Guru dan tenaga kependidikan berperan sebagai pemimpin dan pendukung nilai-nilai masyarakat.

c. Guru dan tenaga kependidikan sebagai fasilitator memungkinkan terciptanya kondisi yang baik bagi subjek didik untuk belajar.

d. Guru dan tenga kependidikan bertanggungjawab atas tercapainya hasil belajar subjek didik.

e. Guru dan tenaga kependidikan dituntut untuk menjadi conoh dalam pengelolaan proses belajar-mengajar bagi calon guru yang menjadi subjek didiknya.

f. Guru dan tenaga kependidikan bertanggungjawab secara professional untuk terus-menerus meningkatkatkan kemampuannya.

g. Guru dan tenaga kependidikan menjunjung tinggi kode etik profesional.

\section{Hakekat Belajar Mengaiar}

a. Peristiwa belajar mengajar teijadi apabila subjek didik secara aktif berinteraksi dengan lingkungan belajar yang diatur oleh guru.

b. Proses belajar mengajar yang efektif memerlukan strategi dan media/teknologi pendidikan yang tepat.

c. Program belajar mengajar dirancang dan diimplikasikan sebagai suatu sistem.

d. Proses dan produk belajar perlu memperoleh perhatian seimbang didalam pelaksanaan kegiata belajar-mengajar.

e. Pembentukan kompetensi profesional memerlukan pengintegrasian fungsional antara teori dan praktek serta materi dan metodeiogi penyampaian.

f. Pembentukan kompetensi professional memerlukan pengalaman lapangan yang bertahap, mulai dari pengenalan medan, latihan keterampilan terbatas sampai dengan pelaksanaan penghayatan tugas-tugas kependidikan secara lengkap aktual.

g. Kriteria keberhasilan yang utama dalam pendidikan profesional adalah 
pendemonstrasian penguasaan kompetensi.

h. Materi pengajaran dan sistem penyampaiannya selalu berkembang.

\section{Hakekat Kelembagaan}

a. LPTK merupakan lembaga pendidikan profesional yang melaksanakan pendidikan tenaga kependidikan dan pengembangan ilmu teknologi kependidikan bagi peningkatan kualitas kehidupan.

b. LPTK menyelenggarakan program-program yang relevan dengan kebutuhan masyarakat baik kualitatif maupun kuantitatif.

c. LPTK dikelola dalam suatu sistem pembinaan yang terpadu dalam rangka pengadaan tenaga kependidikan.

d. LPTK memiliki mekanisme balikan yang efektif untuk meningkatkan kualitas layanannya kepada masyarakat secara terus-menerus.

e. Pendidikan pra-jabatan guru merupakan tanggungjawab bersamaantara LPTK dan sekolah-sekolah pemakai (calon) lulusan.

Hal perlu diperhatikan bahwa Pendidikan berdasarkan kompetensi bagi tenaga kependidikan lainnya memerlukan perangkat asumsi yang berbeda.

\section{Implikasi Landasan Filsafat Pendidikan}

1. Implikasi Bagi Guru

Apabila kita konsekuen terhadap upaya memprofesionalkan pekerjaan guru maka filsafat pendidikan merupakan landasan berpijak yang mutlak. Artinya, sebagai pekerja professional, tidaklah cukup bila seorang guru hanya menguasai apa yang harus diketjakan dan bagaimana mengeijakannya. Kedua penguasaan ini baru tercermin kompetensi seorang tukang.

Di samping penguasaan terhadap apa dan bagaimana tentang tugasnya, seorang guru juga harus menguasai mengapa ia melakukan setiap bagian serta tahap tugasnya itu dengan cara tertentu dan bukan dengan cara yang lain. Jawaban terhadap pertanyaan mengapa itu menunjuk kepada setiap tindakan seorang guru didalam menunaikan tugasnya, yang pada gilirannya harus dapat dipulangkan kepada tujuan-tujuan pendidikan yang mau dicapai, baik tujuan- tujuan yang lebih operasional maupun tujuan-tujuan yang lebih abstrak. Oleh karena itu maka semua keputusan serta perbuatan instruksional serta non- instruksional dalam rangka penunaian tugas-tugas seorang guru dan tenaga kependidikan harus selalu dapat dipertanggungjawabkan secara pendidikan (tugas professional, pemanusiaan dan civic) yang dengan sendirinya melihatnya dalm perspektif yang lebih luas dari pada sekedar pencapaian tujuan-tujuan instruksional khusus, lebih-lebih yang dicekik dengan batasan-batasan behavioral secara berlebihan.

Di muka juga telah dikemukakan bahwa pendidik dan subjek didik melakukan pemanusiaan diri ketika mereka terlihat di dalam masyarakat profesional yang dinamakan pendidikan itu; hanyalah tahap proses pemanusiaan itu yang berbeda, apabila diantara keduanya, yaitu pendidik dan subjek didik, dilakukan perbandingan. Ini 
berarti kelebihan pengalaman, keterampilan dan wawasan yang dimiliki guru sematamata bersifat kebetulan dan sementara, bukan hakiki. Oleh karena itu maka kedua belah pihak terutama harus melihat transaksi personal itu sebagai kesempatan belajar dan khusus untuk guru dan tenaga kependidikan, tertumpang juga tanggungjawab tambahan menyediakan serta mengatur kondisi untuk membelajarkan subjek didik, mengoptimalkan kesempatamn bagi subjek didik untuk menemukan dirinya sendiri, untuk menjadi dirinya sendiri (Learning to Be, Faure $d k k$, 1982). Hanya individuindividu yang demikianlah yang mampu membentuk masyarakat belajar, yaitu masyarakat yang siap menghadapi perubahan-perubahan yang semakin lama semakin laju tanpa kehilangan dirinya.

Apabila demikianlah keadaannya maka sekolah sebagai lembaga pendidikan formal hanya akan mampu menunaikan fungsinya serta tidak kehilangan hak hidupnya didalam masyarakat, kalau ia dapat menjadikan dirinya sebagai pusat pembudayaan, yaitu sebagai tempat bagi manusia untuk meningkatkan martabatnya. Dengan perkataan lain, sekolah harus menjadi pusat pendidikan. Menghasilkan tenaga keija, melaksanakan sosialisasi, membentuk penguasaan ilmu dan teknologi, mengasah otak dan mengeijakan tugas-tugas persekolahan, tetapi yang paling hakiki adalah pembentukan kemampuan dan kemauan untuk meningkatkan martabat kemanusiaan seperti telah diutarakan di muka dengan menggunakan cipta, rasa, karsa dan karya yang dikembangkan dan dibina.

Perlu digarisbawahi di sini adalah tidak dikacaukannya antara bentu dan hakekat Segala ketentuan prasarana dan sarana sekolah pada hakekatnya adalah bentuk yang diharapkan mewadahi hakekat proses pembudayaan subjek didik. Oleh karena itu maka gerakan ini hanya berhenti pada "penerbitan" prasarana dan sarana sedangkan transaksi personal antara subjek didik dan pendidik, antara subjek didik yang satu dengan subjek didik yang lain dan antara warga sekolah dengan masyarakat di luamya masih belum dilandasinya, maka tentu saja proses pembudayaan tidak teijadi. Seperti telah diisyaratkan dimuka, pemberian bobot yang berlebihan kepada kedaulatan subjek didikakan melahirkan anarici sedangkan pemberian bobot yang berlebihan kepada otoritas pendidik akan melahirkan penjajahan dan penjinakan. Kedua orientasi yang ekstrim itu tidak akan menghasilkan pembudayaan manusia.

2. Implikasi bagi Pendidikan Guru dan Tenaga Kependidikan

Tidaklah berlebihan kiranya bila dikatakan bahwa di Indonesia kita belum punya teori tentang pendidikan guru dan tenaga kependidikan. Hal ini tidak mengherankan karena kita masih belum saja menyempatkan diri untuk menyusunnya. Bahkan salahsatu prasaratnya yaitu teori tentang pendidikan sebagimaana diisyaratkan pada bagian-bagian sebelumnya, kita masih belum berhasil memantapkannya. Kalau kita terlibat dalam berbagi kegiatan pembaharuan pendidikan selama ini maka yang diperbaharui adalah pearalatan luamya bukan bangunan dasamya.

Hal diatas itu dikemukakan tanpa samasekali didasari oleh anggapan bahwa 
belum ada diantara kita yang memikirkan masalah pendidikan guru itu. Pikiran-pikiran yang dimaksud memang ada diketengahkan orang tetapi praktis tanpa kecuali dapat dinyatakan sebagi bersifat fragmentaris, tidak menyeluruh. Misalnya, ada yang menyarankan masa belajar yang panjang (atau, lebih cepat, menolak program-program pendidikan guru yang lebih pendek terutama yang diperkenalkan didalam beberapa tahun terakhir ini) ; ada yang menyarankan perlunya ditingkatkan mekanisme seleksi calon guru dan tenaga kependidikan; ada yang menyoroti pentingnya prasarana dan sarana pendidikan guru; dan ada pula yang memusatkan perhatian kepada perbaikan sistem imbalan bagi guru sehingga bisa bersaing dengan jabtan-jabatan lain dimasyarakaL Tentu saja semua saran-saran tersebut diatas memiliki kesahihan, sekurang-kurangnya secara partial, akan tetapi apabila di implementasikan, sebagian atau seluruhnya, belum tentu dapat dihasilkan sistem pendidikan guru dan tenaga kependidikan yang efektif.

Sebaiknya teori pendidikan guru dan tenaga kependidikan yang produktif adalah yang memberi rambu-rambu yang memadai didalam merancang serta mengimplementasikan program pendidikan guru dan tenaga kependidikan yang lulusannya mampu melaksanakan tugas-tugas keguruan didalam konteks pendidikan (tugas professional, kemanusiaan dan civic). Rambu-rambu yang dimaksud disusun dengan mempergunakan bahan-bahan yang diperoleh dari tiga sumber yaitu: pendapat ahli, termasuk yang disangga oleh hasil penelitian ilmiah, analisis tugas kelulusan serta pilihan nilai yang dianut masyarakat.

Rambu-rambu yang dimaksud yang mencerminkan hasil telaahan interpretif, normative dan kritis itu, seperti telah diutarakan didalam bagian uraian dimuka, dirumuskan kedalam perangkat asumsi filosofis yaitu asumsi-asumsi yang memberi rambu-rambu bagi perancang serta implementasi program yang dimaksud. Dengan demikian, perangkat rambu-rambu yang dimaksud merupakan batu ujian didalam menilai perancang dan implementasi program, maupun didalam "mempertahankan" program dari penyimpngan-penyimpangan pelaksanaan ataupun dari serangan-serangan konseptual.

\section{PENUTUP}

Landasan filsafat pendidikan memberi perspektif filosofis yang seyogyanya merupakan "kacamata" yang dikenakan dalam memandang menyikapi serta melaksanakan tugasnya. Oleh karena itu maka ia hams dibentuk bukan hanya mempelajari tentang filsafat, sejarah dan teori pendidikan, psikologi, sosiologi, antropologi atau disiplin ilmu lainnya, akan tetapi dengan memadukan konsep-konsep, prinsip-prinsip serta pendekatan-pendekatannya kepada kerangka konseptual kependidikan.

Dengan demikian maka landasan filsafat pendidikan hams tercermin didalam semua, keputusan serta perbuatan pelaksanaan tugas- tugas keguruan, baik instmksional 
maupun non-instruksional, atau dengan pendekatan lain, semua keputusan serta perbuatan gum yang dimaksud hams bersifat pendidikan.

Akhimya, sebagai pekeija professional gum dfan tenaga kependidikan hams memperoleh persiapan pra-jabatan gum dfan tenaga kependidikan hams dilandasi oleh seperangkat asumsi filosofis yang pada hakekatnya merupakan penjabaran dari konsep yang lebih tepat daripada landasan ilmiah pendidikan dan ilmu pendidikan.

\section{DAFTAR PUSTAKA}

Abudin Nata, Tafsir Ayat-ayat Pendidikan; (Tafsir Ayat-ayat Tarbawy), Jakarta: PT. Raja Grafindo Persada, 2002.

Ahmad Ludjito, "Pendekatan Integralistik Pendidikan Agama Pada Sekolah Indonesia" dalam Chabib Thoha, dkk., (ed.), Reformulasi Filsafat Pendidikan Islam, Pustaka Pelajar, Yogyakarta, 1996.

Ahmad Musthafa al-Maraghi, Tafsir al-Maraghi, Juz I, Beirut: Daar al-Fikr, t.th.

Anna Fatiha, Nilai-nilai Pendidikan Islam Dalam Surah Al-Fatihah, Skipsi Semarang:

Fakultas Tarbiyah IAIN Walisongo Semarang, 2015.

Al-Zamakhsyari, al-Kasyf, Juz I, Beirut-Libanon: Daar al-Kitab al-Ilmiah, t.th.

Bustami A. Gani, dkk., al-Qur'an dan Terjemahnya Madinah: Mujamma' al-Malik Fahdli Thiba'at al-Mushaf al-Syarif, $1418 \mathrm{H}$.

Ibn Katsir al-Damasqy, Tafsir al-Qur'an al-Adhim, Juz I, Beirut: Maktabah al-Nur alIlmiah, t.th.

Irvan, “Konsep Ibadah Dalam Al-Qur'an Kajian Surah Al-Fatihah Ayat 1-7”, Jakarta: Jurusan Pendidikan Agama Islam Fakultas Ilmu Tarbiyah Dan Keguruan Universitas Islam Negri UIN Syarif Hidayatullah Jakarta, 2014.

Jalaluddin al-Syuyuthi, al-Dur al-Mansur fi Tafsir al-Mansur, Juz I, Beirut-Libanon: Daar al-Kitab al-Imiah, t.th.

John W. Santrock, Educational Psychology (Dallas: MCGraw-Hill, 2004). Terj. Tri Wibowo, Psikologi Pendidikan.

Komisi Pendidikan KWI/ WNPK, Sekolah dan Pendidikan Nilai, Editor Em. K. Kaswardi, Pendidikan Nilai Menghadapi Tahun 2000 (Jakarta: Gramedia Widia Sarana, 1993).

Muhaimin dan Abdul, Pemikiran pendidikan Islam, Bandung, Trigenda, 1993.

Muhammad Syatha', Di Kedalaman Samudra Al-Fatihah, Jakarta: Mirqat, 2008.

M.Quraisy Shihab, Tafsir al-Qur'an al-Karim; Tafsir Surat-surat Pendek Berdasarkan 
Urutan Turunnya Wahyu, Bandung: Pustaka al-Hidayah, 1999.

M. Arifin., Ilmu Pendidikan Islam; Tinjauan Teoriti dan Praktis Berdasarkan PendekatanInterdisipliner, Jakarta: Bumi Aksara, 2003.

Nawawi efendi, Aktualisasi Nilai-nilai Tauhid Surah al-Fatihah Pada Pendidikan Islam, Tesis (Surakarta: Program Studi Magister Pendidikan Islam Program Pasca Sarjana Universitas Muhammadiah Surakarta, 2011.

Nasiruddin bin Muhammad al-Syairazi al-Baidhawi, Tafsir al-Baidhawi al-Musamma al-Nur al-Tanzil wa al-Israr al-Ta'wil, Juz I, Beirut-Libanon: Daar al-Kitab alIlmiah, t.th.

Sudirman N., dkk., Ilmu Pendidikan: Kurikulum, Program Pengajaran, Efek Instruksional dan Pengiring, CBSA, Metode Mengajar, Media Pendidikan, Pengelolaan Kelas, Evaluasi Hasil Belajar Cet. III; Bandung: Remadja Karya, 1989.

Sugiyono, Metode Penelitian pendidikan pendekatan Kuantitatif, Kualitatif, dan $R \& D$, Cet 22; Bandung: Alfabeta 2015.

Suharsimi Arikunto, Dasar-dasar Evaluasi Pendidikan (Cet. XII; Jakarta: Bumi Aksara).

Tatang Syarifuddin, Landasan Pendidikan Cet. 1; Jakarta: Direktorat Jenderal Pendidikan Islam Depag. RI., 2009.

Universitas Islam Negeri Alauddin, Pedoman Penulisan Karya Tulis Ilmiah: Makalah, Skripsi, Tesis, Disertasi, dan Laporan Penelitian.

Wina Sanjaya, Kurikulum dan Pembelajaran: TeoridanPraktik Pengembangan Kurikulum Tingkat Satuan Pendidikan KTSP.

Wiratna Sujarweni, Metodologi Penelitian, Cet I; Yogyakarta: 2014. 